\title{
Analisis Energi Pada Proses Pembuatan Kerupuk Udang (Studi Kasus di Pd. SRI TANJUNG, KABUPATEN INDRAMAYU, JAWA BARAT)
}

\author{
Wahyu K Sugandi ${ }^{1)}$, Sarifah Nurjanah ${ }^{1)}$, Reza Permana Aji ${ }^{2}$ \\ ${ }^{1)}$ Alumnus Departemen Teknik Pertanian dan Biosistem, Fakultas Teknologi Industri Pertanian, \\ Universitas Padjadjaran \\ Jl. Bandung Sumedang Km 21, Jatinangor, Sumedang,Jawa Barat, Indonesia 40600 \\ ${ }^{2)}$ Staff Departemen Teknik dan Biosistem, Fakultas Teknologi Industri Pertanian, Universitas Padjadjaran \\ Jl. Bandung Sumedang Km 21, Jatinangor, Sumedang,Jawa Barat, Indonesia 40600 \\ Email : sugandiwahyu@gmail.com
}

\begin{abstract}
ABSTRAK
Energi menjadi kebutuhan vital bagi berbagai aspek kehidupan terutama pada aspek agroindustri. Belum adanya analisis energi yang dilakukan di PD. Sri Tanjung sehingga dibutuhkan data penggunaan energi pembuatan kerupuk udang. Tujuan penelitian ini adalah menganalisis penggunaan energi, mensubsitusi energi langsung dalam konservasi energi, dan menentukan strategi agar meningkatkan efisiensi. Perhitungan penggunaan energi dilakukan pada setiap kegiatan proses pembuatan kerupuk udang, yakni meliputi energi manusia, energi langsung, dan energi tak langsung. Hasil penelitian menunjukan bahwa penggunaan energi dalam proses pembuatan kerupuk udang di PD.Sri Tanjung sebesar 7312,148 MJ/ton kerupuk udang. Penggunan total energi manusia sebesar 151,154 MJ/ton kerupuk udang. Penggunaan total energi langsung sebesar 1992,062 MJ/ton kerupuk udang. Penggunaan total energi tak langsung sebesar 5168,932 MJ/ton kerupuk udang. Besarnya penggunaan energi ditentukan oleh tingkat penggunaan sarana produksi dan jumlah produksi yang dihasilkan, semakin tinggi masukan energi dalam proses produksi dan rendahnya hasil produksi yang diperoleh maka akan semakin efektif dan efisien energi yang digunakan.
\end{abstract}

Kata Kunci : Analisis energi; kerupuk udang; penghematan energi

\begin{abstract}
Energy became a vital need for various aspects of life, especially on the aspect of agroindustry, however the energy analysis had never been done in PD. Sri Tanjung. The objectives of this research were to analyse energy utility, to substitute direct energy in energy conservation, and to determine strategies to improve efficiency. The calculation of energy usage is done at every activity of process of shrimp cracker, which include human energy, direct energy, and indirect energy. The results showed that the use of energy in the process of making shrimp crackers in PD. Sri Tanjung for 7312,148 MJ/ton shrimp crackers. The total use of human energy was 151,154 MJ/ton of shrimp crackers. The total direct energy usage was 1992,062 MJ/ton of shrimp crackers. The total use of indirect energy was 5168,932 MJ/ton of shrimp crackers. The amount of energy usage was determined by the level of use of production facilities and the amount of production produced, the higher the energy input in the production process and the lower production yield would be the more effective and efficient energy used.
\end{abstract}

Keywords: Energy analysis; shrimp crackers; energy saving

Diterima : 2 Maret 2018 ; Disetujui : 20 April 2018; Online Published : -

DOI : $10.24198 /$ jt.vol12n1.10 


\section{PENDAHULUAN}

Dewasa ini, energi menjadi kebutuhan vital bagi berbagai aspek kehidupan terutama pada aspek agroindustri. Moran and Howard (2006) mengungkapkan bahwa energi merupakan sesuatu yang tidak dapat diciptakan dan tidak dapat dimusnahkan. Masalah energi kini menajadi salah satu hal yang sedang difokuskan oleh manusia terutuma kaitannya dengan konservasi energi. Jika penggunaan energi tidak memperhatikan konservasi energi maka akan berdampak kepada efektivitas penggunaan energi dan biaya penggunaanya.

Kemenperin (2015) mengungkapkan bahwa pada aspek industri nasional membutuhkan $44 \%$ dari total ketersediaan energi nasional, aspek transportasi sebesar $36,03 \%$, aspek rumah tangga $11,51 \%$, aspek komersial $4,41 \%$, dan $4,05 \%$ dari total ketersediaan energi nasional. Di kawasan Asia Tenggara, Indonesia menjadi negara terbesar dalam kebutuhan energi, yakni sebesar $44 \%$ dari total kebutuhan energi di kawasan Asia Tenggara.

Audit energi adalah suatu langkah awal pertama untuk melaksanakan kegiatan konservasi energi. Kegiatan penghematan energi (konservasi energi) adalah suatu usaha peningkatan efisiensi dalam penggunaan energi tanpa mengurangi produktivitas produksi dan kini menjadi suatu hal yang sangat penting (Soemohandojo, 2009). Agroindustri kini giat melakukan konservasi energi, bentuk konservasi energi tersebut dengan cara memanajemen penggunaan energi. Manajemen energi pada sektor industri dapat dilakukan dengan cara mengevaluasi penggunaan energi dan berusaha mencari berbagai alternatif agar dapat menghemat penggunaan energi tanpa mengurangi produktivitas. Ketahanan energi nasional dapat dicapai dengan melakukan evaluasi terhadap penggunaan energi.

Pentingnya melakukan evaluasi terhadap penggunaan energi maka diperlukan analisis dan evaluasi penggunaan energi dengan menganalisis karakteristik penggunaan energi pada suatu industri. Hasil dari analisis dan evaluasi dapat memberikan gambaran yang menyeluruh mengenai konsumsi energi pada setiap kegiatan di aspek industri, khususnya industri kerupuk udang.

Industri tidak pernah terlepas dari penggunaan energi, terutama pada kegiatan pembuatan kerupuk udang. Kabupaten Indramayu merupakan daerah industri yang terkenal dengan industri kerupuk udang. Industri kerupuk udang merupakan salah satu industri yang menghasilkan produk makanan yang banyak dikenal di pasaran nasional maupun mancanegara, serta digemari oleh sebagian besar konsumen. Kerupuk memang digemari oleh konsumen, selain sebagai makanan ringan, lauk pauk makanan juga karena rasanya yang gurih, enak dan lezat. Dalam Standar Industri Indonesia (SII) Nomor 0272-90, kerupuk dapat didefinisikan sebagai produk pangan kering yang terbuat dari tapioka atau tepung sagu dengan atau tanpa penambahan bahan makanan atau bahan makanan lainnya yang diijinkan, yang harus disiapkan dengan cara menggoreng atau memanggang sebelum disajikan.

Sentra kerupuk udang berada di Desa Kenanga Kecamatan Sindang, Kabupaten Indramayu. PD. Sri Tanjung merupakan salah satu industri kerupuk udang yang berada didaerah tersebut. Industri kerupuk udang PD. Sri Tanjung berdiri pada tahun 1997. Belum adanya penggunaan energi setiap proses di industri kerupuk udang PD. Sri Tanjung pada kegiatan pembuatan kerupuk. Proses pembuatan kerupuk udang di PD. Sri Tanjung meliputi persiapan bahan baku, penggilingan udang, pencampuran bahan baku dengan udang, pencetakan adonan, pengukusan adonan, pendinginan adonan, pemotongan adonan, pengeringan adonan dan pengemasan. Produk akhir berupa kerupuk udang dapat dikelompokan menjadi tiga yaitu kualitas super, kualitas I, dan kualitas blaster. Perbedaan dari ketiga kualitas tersebut adalah jumlah udangnya. 
Konsumsi energi pada kegiatan pembuatan kerupuk udang di PD. Sri Tanjung saat ini belum diketahui berapa jumlah energi yang dibutuhkannya. Diperlukan analisis energi untuk mengetahui gambaran konsumsi energi agar sumber-sumber pemborosan energi dapat diketahui untuk meningkatkan efisiensi pada proses pembuatan kerupuk udang. Hasil dari audit energi yang dilakukan di PD. Sri Tanjung kemudian akan digunakan sebagai pedoman untuk mencapai tingkat efisiensi yang lebih baik sehingga akan meningkatkan daya saing produknya melalui strategi-strategi konservasi energi dan pengembangan teknologi menuju alternatif sumber-sumber energi yang terdapat di PD. Sri Tanjung.

\section{METODOLOGI}

Penelitian ini dilaksanakan di PD. Sri Tanjung, Kecamatan Sindang, Kabupaten Indramayu, Jawa Barat. Kegiatan penelitian ini dilaksanakan pada bulan Juni 2017 sampai dengan Agustus 2017

\section{Alat dan Bahan}

Alat yang digunakan yaitu stopwatch, clampmeter, thermometer infrared, timbangan, mesin mixer, mesin pencetak adonan, mesin pemotong. Sedangkan bahan yang digunakan yaitu data primer dan data sekunder. Data primer diperoleh dari penelitian secara langsung di tempat dengan proses pengamatan, pengukuran, wawancara, mencatat dan menghitung. Data sekunder yang digunakan yaitu data kebutuhan energi untuk proses pembuatan kerupuk udang berdasarkan jadwal kegiatan oleh kepala bagian produksi, waktu yang diperlukan untuk setiap jenis kegiatan, jumlah tenaga kerja, jumlah dan jenis alat dan mesin, dan semua sarana produksi yang digunakan maupun studi literatur.

\section{Tahapan Penelitian}

Diagram alir tahapan penelitian dapat dilihat pada Gambar 1.

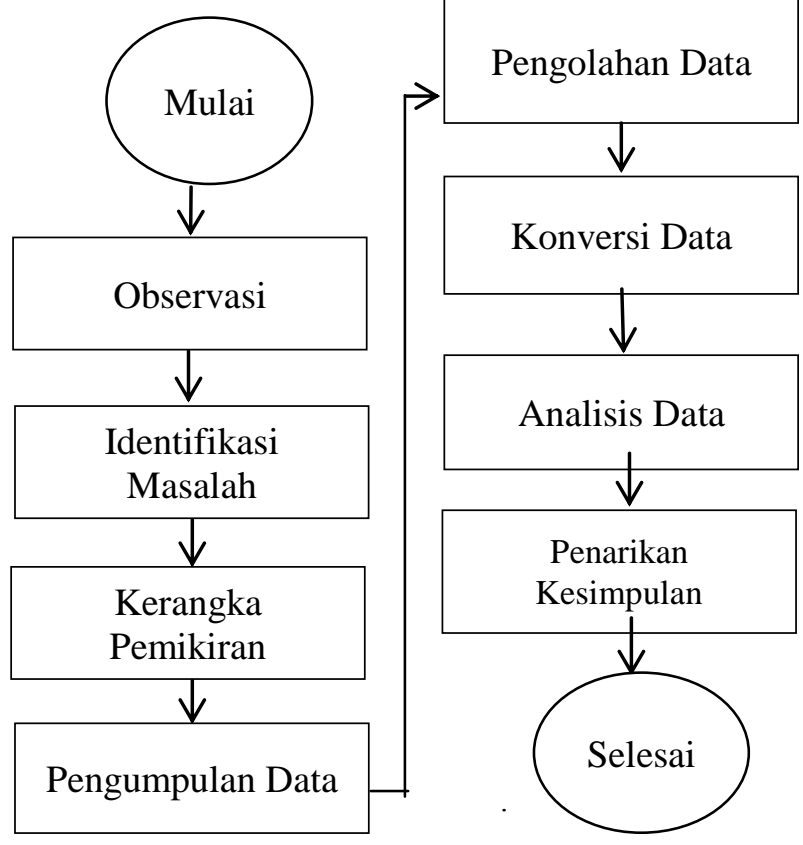

\section{Gambar 1. Diagram Alir Tahapan} Penelitian

\section{Obeservasi}

Bedasarkan pengamatan yang dilakukan, PD. Sri Tanjung merupakan salah satu industri kerupuk udang yang berada di Kabupaten Indramayu. Proses pembuatan kerupuk udang sendiri belum diketahui berapa jumlah energi yang digunakan sehingga diperlukan analisis energi. Analisis energi ini kemudia digunakan untuk meningkatkan efisisensi penggunaan energi sehingga dampaknya akan mengurangi pemborosan yang terjadi

\section{Identifikasi Masalah}

Bedasarkan hasil observasi diperoleh identifikasi masalah, yakni belum adanya analisis energi pada proses pembuatan kerupuk udang. Seberapa besar peran energi matahari dalam proses pengeringan kerupuk udang dan bagaimana langkah dan strategi menuju efisiensi penggunaan energi dalam proses pembuatan kerupuk udang.

\section{Kerangka Pemikiran}

Analisis energi perlu dilakukan di industri kerupuk udang PD. Sri Tanjung agar mengetahui energi yang digunakan pada proses pembuatan udang. Tahapan proses pembuatan kerupuk udang meliputi persiapan 
bahan baku, penggilingan udang, pencampuran bahan baku dengan udang, pencetakan adonan, pengukusan adonan, pendinginan adonan, pemotongan adonan, pengeringan adonan dan pengemasan. Pada setiap proses tersebut membutuhkan energi yang dapat diperhitungkan bersarannya. Data yang didapatkan untuk menganalisis energi pembuatan kerupuk udang dapat digunakan untuk mengetahui kebutuhan konsumsi energi yang dibutuhkan.

Kebutuhan konsumsi energi tersebut akan dibandingkan dengan hasil produk kerupuk udang. Hal ini untuk mengetahui apakah sudah sebanding antara energi yang digunakan dengan hasil yang diperoleh pada setiap kegiatan pembuatan kerupuk udang. Semua tahapan pada kegiatan pembuatan kerupuk udang akan dilakukan penilaian dan analisis energi untuk menghitung bedasarkan penggunaan energi pada setiap kegiatan. Hasil dari analisis energi ini kemudian dilanjutkan dengan melakukan evaluasi sehingga dapat meningkatkan efisiensi penggunaan energi selama proses pembuatan kerupuk udang di PD. Sri Tanjung.

\section{Pengumpulan Data}

Pengamatan dan pengumpulan data penggunaan energi selama proses pembuatan kerupuk udang dilakukan berdasarkan: jadwal kegiatan pekerja (1); waktu yang diperlukan untuk setiap kegiatan (2); jumlah tenaga kerja, alat dan mesin (3); faktor yang terdapat dalam proses produksi (4); identifikasi bentuk dan jumlah energi (5).

\section{Pengolahan data}

Pada tahap ini dilakukan perhitungan penggunaan energi menggunakan persamaanpersamaan penggunaan energi. Perhitungan penggunaan energi pada proses pembuatan kerupuk udang mengikuti persamaan berikut:

\section{Energi Manusia}

$\mathrm{EBS}=\mathrm{HOK} \times \mathrm{JK} \times \mathrm{cb} \times \mathrm{Rd}$

EBS = Energi biologis produksi (MJ/ha)

HOK = Jumlah hari orang bekerja per ton

$\mathrm{JK}=$ Jumlah jam kerja per hari (jam/hari)

$\mathrm{Cb}=$ Nilai unit energi biologis $(\mathrm{MJ} / \mathrm{jam})$
$\mathrm{Rd}$ $=$ Rendemen hasil kegiatan yang berlangsung $(\%)$

\section{Energi Langsung}

a. Energi Bahan Bakar

Elt $=($ KL $\times$ CL $\times \mathrm{Rd}) / \mathrm{CH}$

Elt= Energi bahan bakar yang terpakai (MJ/ton)

$\mathrm{KL}=$ Konsumsi bahan bakar padat $(\mathrm{kg} / \mathrm{jam})$

$\mathrm{Cl}=$ Nilai unit energi bahan bakar $(\mathrm{MJ} / \mathrm{kg})$

$\mathrm{Rd}=$ Rendemen hasil kegiatan yang berlangsung $(\%)$

$\mathrm{CH}=$ Kapasitas hasil alat (ton/jam)

b. Energi Listrik

Elk $=(\mathrm{P} \times \mathrm{t} \times \mathrm{n}) / \mathrm{m}$

$\mathrm{P}=\mathrm{V} \times \mathrm{I} \times \operatorname{Cos} \theta \times$ konstanta fasa

Nilai $\mathrm{P}$ untuk 3 fasa digunakan persamaan:

$\mathrm{P}=\mathrm{V} \times \mathrm{I} \times \operatorname{Cos} \theta \times \sqrt{3}$

Sedangkan untuk fasa tunggal, konstanta fasa adalah 1

Elk= energi listrik yang digunakan (MJ/ton)

$\mathrm{t}=$ lama waktu penggunaan alat (detik)

$\mathrm{n}=$ Efisiensi peralatan elektronik $(0,8)$

$\mathrm{V}=$ tegangan (volt)

$\mathrm{I}=$ arus listrik (ampere)

$\operatorname{Cos} \theta=$ faktor daya $(0,8)$

$\mathrm{P}=$ daya $(\mathrm{kW})$

$\mathrm{m}=$ jumlah produksi (ton)

3. Energi Tidak Langsung Alat dan Mesin Eas $=$

$$
\frac{(M 1(c e m+c e f)) \times((0,02+0,333 \times T A R) R d)}{C H \times N}
$$

Eas = Energi tidak langsung terpakai dari mesin atau alat $(\mathrm{MJ} / \mathrm{kg})$

$\mathrm{M}_{1}=$ Massa total mesin $(\mathrm{kg})$

$\mathrm{Cem}=$ Nilai unit energi tak lagsung produksi bahan baku (MJ/kg)

Cef = Nilai unit energi tak langsung untuk fabrikasi alat $(\mathrm{MJ} / \mathrm{kg})$

$\mathrm{TAR}=$ Nilai $\%$ total akumulasi pemakaian, perbaikan, dan pemeliharaan alat

$\mathrm{Rd}=$ Rendemen hasil kegiatan yang berlangsung (\%)

$\mathrm{CH}=$ Kapasitas hasil alat (ton/jam)

$\mathrm{N}=$ Umur ekonomis alat (jam)

\section{Energi Tak Langsung Bahan}

$\mathrm{Ee}=\mathrm{CTL} \times \mathrm{KT}$

$\mathrm{Ee}=$ Energi tidak langsung dari bahan yang digunakan (MJ/kg produk) 
CTL = Nilai energi tidak langsung bahan (MJ/kg bahan)

$\mathrm{KT}=$ Konsumsi bahan per ton $(\mathrm{kg}$ bahan $/ \mathrm{kg}$ produk)

\section{Konversi data}

Pada tahap ini dilakukan konversi data dari hasil pengolahan data menjadi satuan $\mathrm{MJ} /$ ton.

\section{Analisis data}

Pada tahap ini dilakukan analisis dari hasil konversi data dengan menggunakan metode SWOT untuk menentukan langkah menuju penghematan energi.

\section{Analisis SWOT}

Menurut Rangkuti

(2004)

mengungkapkan bahwa analisis SWOT adalah identifikasi berbagai faktor secara sistematis untuk merumuskan strategi. Analisis ini berdasarkan pada logika yang dapat memaksimalkan kekuatan (strength) dan peluang (opportunity), namum secara bersamaan dapat meminimalkan kelemahan (weakness) dan ancaman (threats).

\section{HASIL DAN PEMBAHASAN}

Proses pembuatan kerupuk udang di PD. Sri Tanjung memiliki 9 kegiatan, yaitu proses persiapan bahan baku, penggilingan udang, pencampuran bahan baku dengan udang, pencetakan adonan, pengukusan adonan, pendinginan adonan, pemotongan adonan, pengeringan adonan dan pengemasan. Pada kesembilan proses pembuatan kerupuk udang tersebut, masing-masing memiliki nilai energi yang akan dianalisis penggunaan energinya.

Energi yang diperhitungkan meliputi penggunaan energi yang berasal dari energi biologis atau energi manusia, energi langsung bahan bakar dan energi langsung listrik, dan energi tidak langsung (embodied energy) dari alat dan mesin pertanian dan bahan yang digunakan selama proses pembuatan kerupuk udang.

Penggunaan energi total pada proses pembuatan kerupuk udang di PD. Sri Tanjung sebesar 7312,148 MJ/ton kerupuk udang. Penggunaan energi tersebut dirinci menurut jenisnya dan dikelompokkan bedasarkan tahapan proses dari persiapan bahan baku hingga pengemasan. Rincian penggunaan energi total pembuatan kerupuk udang disajikan dalam Tabel 1.

\begin{tabular}{|c|c|c|c|c|c|c|}
\hline No & Proses & $\begin{array}{c}\text { Energi } \\
\text { Manusia } \\
\text { (MJ/ton) }\end{array}$ & $\begin{array}{c}\text { Energi } \\
\text { Langsung } \\
\text { (MJ/ton) }\end{array}$ & $\begin{array}{c}\text { Energi Tak } \\
\text { Langsung } \\
\text { (MJ/ton) }\end{array}$ & $\begin{array}{c}\text { Total } \\
\text { Energi } \\
\text { (MJ/ton) }\end{array}$ & Persentase \\
\hline 1 & Perisiapan bahan baku & 2,84 & - & 4804,61 & 4807,45 & $65,75 \%$ \\
\hline 2 & Penggilingan udang & 1,09 & 4,00 & 108,52 & 113,61 & $1,55 \%$ \\
\hline 3 & $\begin{array}{l}\text { Pencampuran bahan } \\
\text { baku dengan udang }\end{array}$ & 3,53 & 28,00 & 17,12 & 48,65 & $0,67 \%$ \\
\hline 4 & Pencetakan adonan & 2,65 & 9,00 & 27,55 & 39,20 & $0,54 \%$ \\
\hline 5 & Pengukusan adonan & 4,40 & 1949,06 & 28,47 & 1981,93 & $27,10 \%$ \\
\hline 6 & Pendinginan adonan & 0,88 & - & 31,77 & 32,65 & $0,45 \%$ \\
\hline 7 & Pemotongan adonan & 42,48 & 2,00 & 6,55 & 51,03 & $0,70 \%$ \\
\hline 8 & Pengeringan adonan & 77,64 & - & 2,43 & 80,07 & $1,10 \%$ \\
\hline 9 & Pengemasan & 15,64 & - & 141,91 & 157,56 & $2,15 \%$ \\
\hline & Total & 151,15 & 1992,06 & 5168,93 & 7312,15 & $100,00 \%$ \\
\hline
\end{tabular}

Dapat dilihat pada Tabel 1 bahwa energi terbesar terdapat pada energi tak langsung sebsar 5168,932 MJ/ton kerupuk udang dengan presentase dari energi total sebesar 
$70,689 \%$. Hal tersebut dikarenakan energi tak langsung bahan sebagai penyumbang energi terbesar pada proses persiapan bahan baku. Energi tak langsung bernilai sangat besar karena energi yang digunakan secara tidak langsung atau energi yang pabrikasi pembuatan alat dan bahan yang terkandung dalam proses pembuatan kerupuk udang. Energi yang terkecil terdapat pada energi manusia sebesar 151,154 MJ/ton kerupuk udang dengan presentase dari energi total sebesar 2,068\%. Energi manusia yang terbesar terdapat pada proses pengeringan adonan. Hal tersebut dikarenakan pekerja yang terlibat pada proses pengeringan adonan termasuk dalam klasifikasi perkaan berat dan pada proses ini membutuhkan 14 orang pekerja. Energi manusia pada penelitian kali ini belum mempertimbangkan jenis kelamin laki-laki maupun perempuan sehingga diperlukan penelitian berikutnya agar lebih akurat dalam penggunaan energi manusia. Energi langsung yang digunakan pada proses pembuatan kerupuk udang sebesar 1992,062 MJ/ton kerupuk udang dengan presentase dari energi total sebesar 27,243\%. Energi langsung terbesar terdapat pada proses pengukusan adonan. Hal tersebut dikarenakan proses pengukusan melibatkan kayu bakar sebagai bahan bakar pada proses ini. Energi langsung kayu bakar merupakan energi yang besar sehingga nilai energi pada proses ini besar.

Pendekatan kuantitatif analisis SWOT bedasarkan pengamatan lapangan yang dilakukan di PD. Sri Tanjung. Setelah mengetahui kekuatan, kelemahan, peluang dan ancaman yang ada di PD. Sri Tanjing maka selanjutnya adalah melakukan analisis terhadap faktor-faktor tersebut dimana didapat hasul pengurangan $\mathrm{S}-\mathrm{W}$ sebagai sumbu $\mathrm{X}$ dengan nilai negatif sebesar 1,99 dan faktor O$\mathrm{T}$ sebagai sumbu $\mathrm{Y}$ dengan nilai positif sebesar 8,555. Untuk menentukan strategi yang dapat digunakan agar proses pembuatan kerupuk udang dapat berlangsung lebih efisien dapat digunakan kuadran SWOT yang terdapat pada Gambar 3.

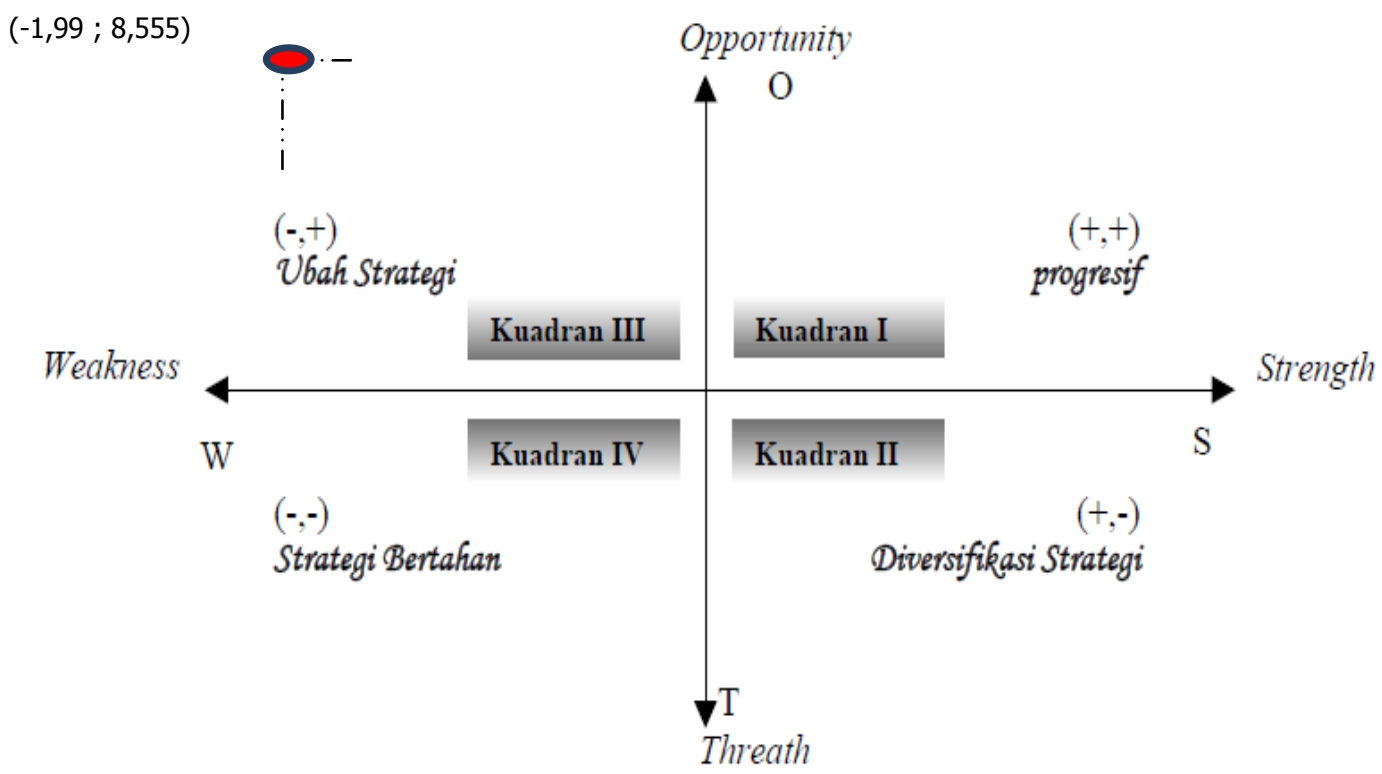

Gambar 2. Kuadran SWOT

Didapatkan kuadran SWOT sesuai dengan hasil pendekatan kuantitatif analisis SWOT, maka dapat diketahui strategi yang digunakan untuk meningkatkan nilai efisiensi energi yang digunakan dalam proses pembuatan kerupuk udang. Dalam metode SWOT jika $(X, Y)$ bernilai $(-1,99 ; 8,555)$ hal ini menandakan strategi PD. Sri Tanjung berada 
pada kuadran III yaitu strategi WO, dimana solusi yang diberikan adalah dengan cara ubah strategi dengan cara memperbaiki kelemahan internal dengan cara mengambil keuntungan dari peluang eksternal. Adapun langkahlangkah yang harus dilakukan sebagai berikut:

a. Kayu bakar dapat diganti dengan briket untuk meningkatkan efisiensi energi pembakaran pada proses pengukusan adonan.

b. Pemberian isolator pada tungku agar tidak dapat terjadi kebocoran panas pada dinding tungku sehingga efisiensi proses pengukusan dapat meningkat dan mengurangi biaya.

c. Pembaruan alat dan mesin dapat dilakukan dengan menggunakan mesin baru, dimana dua proses dapat disatukan. Misalkan pada proses pencampuran bahan baku dengan udang dapat disatukan dengan proses pencetakan.

d. Dikarenakan mesin tidak hanya memproses udang sebagai bahan baku sehingga pengembangan pasar dapat leluasa dilakukan.

Solusi yang diberikan di atas merupakan solusi strategi secara umum. Diketahui strategi yang digunakan yaitu WO maka hal yang dilakukan adalah memanfaatkan peluang yang ada untuk mengurangi dan menghilangkan kekurangan yang terdapat pada proses pembuatan kerupuk udang di PD. Sri Tanjung.

Konservasi energi merupakan usaha untuk memelihara dan melestarikan sumber energi yang ada sehingga tidak terjadi pemborosan energi yang berarti dan membawa dampak negatif dalam suatu industri. Konservasi energi bermanfaat bukan hanya untuk menekan konsumsi dan biaya konsumsi energi, namun juga memberikan dampak yang lebih baik terhadap lingkungan.

Pada proses pembuatan kerupuk udang, beberapa usaha penghematan energi yang dapat dilakukan adalah secara teknis maupun non teknis. Secara teknis mengganti bahan bakar kayu menjadi briket, menggabungkan dua kegiatan menjadi satu dengan mengganti mesin sehingga dapat menekan waktu kerja, dan memberikan isolator pada dinding tungku sehingga dapat menekan kebocoran panas. Secara non teknis adalah kebiasaan pekerja harus diubah sehingga dapat meningkatkan efisiensi waktu kerja.

Bedasarkan analisis SWOT, briket dapat menjadi peluang untuk mengganti kayu bakar pada proses pengukusan adonan. Bedasarkan perhitungan biaya pada Lampiran 23 subsitusi kayu bakar dengan briket dapat menghemat biaya sebesar $\mathrm{Rp}$ 17.143,709. Hal tersebut dikarenakan, nilai unit energi briket lebih besar dari kayu bakar. Menurut Jamilatun (2008), nilai unit energi dari briket sebesar $15000 \mathrm{MJ} / \mathrm{kg}$.

\section{KESIMPULAN}

Kesimpulan pada penelitian mengenai analisis energi pada proses pembuatan kerupuk udang yang dilakukan di PD. Sri Tanjung, Kabupaten Indramayu, Jawa Barat, yaitu:

a. Penggunaan energi total pada proses pembuatan kerupuk udang sebesar 7312,148 MJ/ton dengan rincian pada setiap kegiatan yakni, pada proses pengeringan adonan sebesar 4.804,611 $\mathrm{MJ} /$ ton, proses penggilingan udang sebesar $113,613 \mathrm{MJ} /$ ton, proses pencampuran bahan baku dengan udang sebesar $48,645 \mathrm{MJ} /$ ton, proses pencetakan adonan sebesar 39,202 MJ/ton, proses pengukusan adonan sebesar 1981,930 MJ/ton, proses pendinginan adonan sebesar 32,650 $\mathrm{MJ} /$ ton, proses pemotongan adonan sebesar 51,032 MJ/ton, proses pengeringan adonan sebesar $80,072 \mathrm{MJ} /$ ton, dan proses pengemasan sebesar $157,558 \mathrm{MJ} /$ ton.

b. Penggunaan energi terbesar pada kegiatan persiapan adonan sebesar 4807,446 MJ/ton dan yang terkecil pada kegiatan pendingan adonan dengan nilai sebesar 32,650 $\mathrm{MJ} /$ ton. Pada kegiatan persiapan bahan baku yang terbesar merupakan energi tak lansungnya sehingga dapat dikatakan bahwa energi tersebut tidak dikaitan ke dalam analisis energi karena energi tak 
langsung tidak dapat hemat nilai energinya.

c. Penggunaan energi total manusia pada proses pembuatan kerupuk udang sebesar 151,154 dengan presentase dari energi total sebesar $2,067 \%$. Penggunaan total energi langsung pada proses pembuatan kerupuk udang sebesar 1992,062 MJ/ton dengan presentase dari energi total sebesar $27,243 \%$. Penggunaan total energi tidak langsung pada proses pembuatan kerupuk udang sebesar 5168,932 MJ/ton dengan presentase dari energi total sebesar 70,690\%.

d. Penghematan energi dapat dilakukan dengan melakukan subsitusi energi langsung kayu bakar dengan menggunakan briket. Biaya penggunaan kayu bakar per hari sebesar Rp. 17.858,365. Biaya penggunaan briket per hari sebesar Rp. 714,656. Terjadi penghematan sebesar $\mathrm{Rp}$ 17.143,709 per hari.

e. Bedasarkan analisis SWOT, penghematan energi dapat dilakukan dengan cara mensubsitusi kayu bakar dengan briket, membarikan isolator pada dinding tungku, dan menggabungkan dua kegiatan menjadi satu pada kegiatan pencampuran bahan baku dengan udang dan pencetakan adonan.

\section{DAFTAR PUSTAKA}

Abdullah, K., A. K. Irwanto, N. Siregar, S. E. Agustina, A. H. Tambunan, E. Hartulistiyoso, dan Y. A. Purwano. 1998. Energi dan Listrik Pertanian. Japan International Cooperation Agency. Bogor: Institut Pertanian Bogor.

Afifah, D. dan Anjani G. 2008. Sistem Produksi dan Pengawasan Mutu Kerupuk Udang Berkualitas Ekspor. Diakses pada http://eprints.undip.ac.id/855/2/SISTEM _PRODUKSI_DAN_PENGAWASAN_ MUTU_KERUPUK_UDANG.pdf.

(Diakses pada tanggal 21 Maret 2017 pukul 23.00)
Astawan, M dan M.W. Astawan. 1991. Teknologi Pengolahan Pangan Nabati Tepat Guna. Akademi Pressido, Jakarta.

Brooker, D., Bakker-Arkema and C. Hall. 1974. Drying Cereal Grains. The AVI Pub. Co. Inc. Westport. Connecticut.

Dede, P. 2014. Kajian Energi Proses Pengolahan Industri Tapioka Rakyat Skala Menengah. Fakultas Pertanian, Universitas Negeri Lampung. Lampung

Hall, D. O., Rosillo, and Calle. 1985. Energy and Resource Quality: The Ecology of Economic Process. New York: Jhon Willey \& Sons Inc.

Hasan. 2002. Pokok-pokok Materi Metodologi Penelitian dan Aplikasinya. Ghalian Indonesia, Jakarta.

Hasan, H. 2012. Perancangan Pembangkit Listrik Tenaga Surya di Pulau Sugi. Jurnal Riset dan Teknologi Kelautan (JRTK). Volume 10, Nomor 2, JuliDesember 2012

Hendersoon, S. M. and Perry, R. L. (1976) Agricultural Process Engineering, 3rd Edition, Wiley, New York.

Indrayana. 2001. Analisis Kebutuhan Energi pada Proses Produksi Gula di PT. PG. Rajawali II Unit PG. Jatitujuh. Fakultas Teknologi Pertanian, Institut Pertanian Bogor. Bogor

Jamilatun, Siti. 2008. Sifat-sifat Penyalaan dan Pembakaran Briket Biomassa, Briket Batu Bara, dan Arang Kayu. Jurnal Rekayasa Proses, Vol. 2, No. 2, 2008.

Kemertrian Energi dan Sumber Daya Mineral. 2017. Tarif Dasar Listrik PLN Agustus 2017. Terdapat di: http://listrik.org/pln/tarif-dasar-listrikpln/. (diakses pada tanggal 28 Agustus 2017 pukul 22.30 WIB)

Kemenperin. 2015. Konsumsi Energi Seiring Pertumbuhan Industri. Terdapat di: http://www.kemenperin.go.id/artikel/989 7/Konsumsi-Energi-Seiring-

Pertumbuhan-Industri. (diakses pada 
tanggal 22 Febuari 2017 pukul 21.45 WIB)

Kementerian Pertanian. 2015. Membuat Kerupuk Udang. Terdapat pada: http://cybex.pertanian.go.id/materilokalit a/detail/10783. diakses pada tanggal 25 Agustus 2017 pukul 00.15 WIB

Koswara, S. 2009. Pengolahan Aneka Kerupuk. Diakses pada http://tekpan.unimus.ac.id/wpcontent/uploads/2013/07/PENGOLAHA N-ANEKA-K-E-R-U-P-U-K.pdf. (Diakses pada tanggal 22 Maret 2017 pukul 21.00)

Malcolm, C dan Hamdy A. 1991. Halophyles and Biosaline Agriculture. New York: Marcel Dekker, Inc.

Moran, M.J dan Howard, N.S. 2006. Fundamental of Engineering Thermodynamic, 5th Edition. Amerika Serikat: John Wiley and Sons Inc.

Pimentel, D. 1990. Handbook of Energy for World Agriculture. New York: Elsevier Science Publishing Co., Inc.

Purnomo, A.H., Cholik, A., dan Bustaman, S. 1989. Preliminary Study on Preparation of Kerupuk Ikan. Lembaga Penelitian Teknologi Perikanan Laut No. 25. Balai Penelitian Perikanan Laut. Departemen Pertanian Jakarta.
Prayitno, S. dan Susanto, T. 2001. Kupang dan Produk Olahannya. Yogyakarta: Kanisius.

Rangkuti, F. 2004. Analisis SWOT Teknik Membedah Kasus Bisnis. Jakarta: PT. Gramedia.

Rita, R. 2013. Analisis Budidaya Ikan Tambak. Jakarta: Penebar Plus.

Stout. 1992. Energy in Farm Production. New York: Elsevier Science Publishing Co., Inc.

Suprapti, L. 2004. Aneka Olahan Udang. Yogyakarta: Kanisius.

Suprapti, L. 2005. Kerupuk Udang Sidoarjo. Yogyakarta: Kanisius.

Suzuki, T. 1981. Fish Krill Protein Processing Technology. Aplied Science Publisher, Ltd. London.

Syarief, R. 1989. Teknologi Pengemasan Pangan. PAU Pangan dan Gizi IPB. Bogor.

Syarif, S. dan Soenarjo, E. 1985. Teknologi Pengemasan, Penuntun Praktikum. Jurusan Teknologi Pangan dan Gizi, Fateta. IPB, Bogor.

Toledo, Romeo. 1980. Fundamentals Of Food Process Engineering (Second Edition). Amerika Serikat: University of Georgia.

Wahyono, R. dan Marzuki. 2000. Pembuatan Aneka Kerupuk. Surabaya: Trubus Agrisarana. 